\title{
Mystifying moments in Bible interpretation: An exploration of some implied backgrounds to three kinds of unusual Bible readings
}

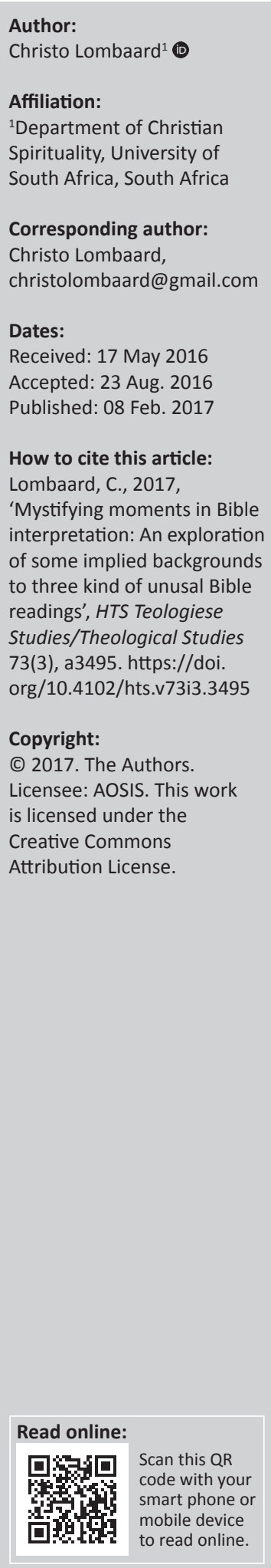

This contribution is part of a series on Methodology and Biblical Spirituality. In this, the fourth contribution, the scope is widened; more practical-analytically oriented, three thoroughly different but nevertheless all unusual kinds of interpretations of the Bible are described, characterised and contextualised. Namely:

- In order to explain what are perceived as textual anomalies, some Old Testament authors have been described by US-based medical practitioners as having suffered psychiatric dysfunctions.

- The Garden of Eden from Genesis 2 and further has been located by a recently diseased Nigerian scholar as having been in her home country, with a Nigerian race having been the predecessors of biblical Adam and Eve.

- Rastafarians, primarily Jamaica-based, regard marijuana as a holy herb and find direct support for their religious use of this plant in the Bible.

However strange such 'mystifying' interpretations may seem within the theological mainstreams of Judeo-Christianity, there is more to these kinds of interpretations than simple whim. Certain cultural conditions along with personal, particularly spiritual, commitments enable these interpretations, which must be taken seriously in order to come to a fuller understanding of the text-interpreter dynamic. These then can cast at least some form of reflective light on the more usual current biblical-interpretative mainstreams within Judeo-Christianity, posing in a new light the question of what constitutes legitimate interpretations, also within mainstream interpretations, as religiously inclined people try to live their lives in the light of Scripture.

\section{Biblical and Umbilical Spirituality?}

In the discipline of Biblical Spirituality (cf. Welzen 2011:37-60 for an overview of current approaches to this relatively new research field), it is not only the way in which, historically, impulses of faith, along with all other factors usually studied by Bible scholars, have played their part in the birth and development of the Bible texts (cf. Lombaard 2014:472-488) that are investigated, namely exegetically. Another main focus of this discipline is the analysis of manners in which, later in history (e.g. Huls 2006:84-98) and up to current times, the Bible is related to, interpreted and employed by its readers (cf. Lombaard 2015b:1-13). The latter analysis may be done following a phenomenologically descriptive approach (e.g. Lombaard 2012:139-169) or in a more evaluative-critical manner (e.g. in a more popular mode, Lombaard 2010). It is however different from, though not unrelated to, Reader Response engagements, typical of for instance ecological, gender and African readings of the biblical text; as important as all these matters are, the aspect of faith as the experience of the Divine, also as it relates to issues such as those just mentioned, is namely kept in focus within the discipline of Biblical Spirituality. Neither the world nor God is given up in the quest for meaning, here as it relates to the Bible in both historical and contemporary contexts.

What is offered here, in this contribution, are analyses of the second kind: not primarily exegetical (although, to put my interpretative cards on the table, the standard academic protocols of exegesis are here assumed as background), but contemporary-analytical. Three instances of what in most mainstream exegetical conversations will be understood as unusual cases of Bible interpretation are analysed. This study namely forms part of a research trajectory on relationships between aspects of spirituality ${ }^{1}$ and the actual or implied methodology of interpreting the Bible. In the first publication along these lines, 'Biblical Spirituality and interdisciplinarity: the discipline at 1.The fullest description of the phenomenon and the academic discipline of spirituality is found in the 2000 volume by Kees Waaijman, titled Spiritualiteit: vormen, grondslagen, patronen, and its various translations. 
cross-methodological intersection' (Lombaard 2011:211-225) the problematics was posed in relation to the academic discipline of Spirituality. In 'Mysticism and/in the Old Testament: Methodological orientation and a textual example' (Lombaard 2015a:1-5), the problematics was posed in relation to the field of Mysticism. As one analysis of how these dynamics play out specifically related to the Psalms, then followed 'Hol(e)y Texts; Hol(e)y Lives: on the Psalms and Spirituality. With particular attention to Thessalonia DePrince, Thomas Merton and Beat Weber - described, compared and evaluated' (Lombaard 2015b:1-13). ${ }^{2}$ In this contribution, the latter scope is widened; more practicalanalytically oriented, three thoroughly different but nevertheless all unusual kinds of interpretations of the Bible are described, characterised and contextualised.

The three instances presented here, from quite a diverse geographical spread, are namely:

- In order to explain what are perceived as textual anomalies, some Old Testament authors have been described by US-based medical practitioners as having suffered from psychiatric dysfunctions.

- The Garden of Eden from Genesis 2 and further has been located by a recently diseased Nigerian scholar as having been in her home country, with a Nigerian race having been the predecessors of a biblical Adam and Eve.

- Rastafarians, primarily Jamaica-based, regard marijuana as a holy herb and find direct support for their religious use of this plant in the Bible.

However, strange such 'mystifying' interpretations may seem within the theological mainstreams of Judeo-Christianity, there is more to these kinds of interpretations than simple whim. Certain cultural conditions along with personal, particularly spiritual, commitments enable these interpretations, which must be taken seriously in order to come to a fuller understanding of the text-interpreter dynamic. These then can cast some form of reflective light on the more usual current biblical-interpretative mainstreams within Judeo-Christianity, posing in a new light the question of what constitutes legitimate interpretation, also within mainstream hermeneutics, as religiously inclined people try to live their lives in the light of Scripture. Mystifying as these interpretations may seem, they are therefore more than just interesting for their 'otherness'; these are sincere attempts at trying to relate aspects of life to the Bible texts, with these texts understood on the basis of certain assumptions. Though these interpretations may lack academic respectability and will never find their way as examples of exemplary hermeneutics into text books for students of biblical literature, they do show personal integrity; these authors sincerely seek to relate their topic of interest to their understanding of the Bible.

This investigation is therefore undertaken not for the sake of making light on 'weird' Bible readings, which would be intellectually non-productive. Rather, the intentions here are hermeneutical: to understand honestly and sympathetically

2.Following on the present contribution will be the publication of Lombaard (2016). and then to interpret. Firstly, therefore, follows in each instance an attempt at brief but fair description of these three cases and, second, suggestions of some insights from cultural-spiritual dynamics on why such understandings could be brought forth. This then opens the door to considering also wherein the validity of broadly accepted interpretations could be said to be found - an exercise that leads to some quite disconcerting questions.

In all three instances discussed below, it must be stressed that the interpretations are indeed dearly held; they are honestly believed by those who propose them and/or subscribed to them, and those interpretations are socially reinforced by those around the 'exegetes'. Thus, these readings are not intended to be overtly humorous, as is the case with for instance British comedian Spike Milligan's 1994 parody The Bible - The Old Testament according to Spike Milligan or South African cultural icon Koos Kombuis's 2003 spoof The secret diary of God (aged 91/2 million trillion years). There is in all three cases investigated here a sense of integrity to be identified amongst those who propose these Bible readings, which render them worthy objects of intellectual inquiry. These are namely (re-)readings of aspects of the biblical tradition within modern cultures (cf. Goedgebuure 1993 for broader perspectives), showing that as much as Scripture lies at the heart of Theology (cf. the essays collected in Mahoney 2000), it is in many respects still present also in broader culture as an interpretative centre (not meant here as the interpretative centre). This, even as an umbilical cord, in some manner existentially linking people to God. Spirituality - the experience of faith, reflexively - deeply links Bible and recipient or interpreter (be the latter individual believers, churches or cultures). This is clear in each of the instances discussed below, where the Bible forms a fundamentally important point of orientation for the interpreters involved. The spiritually constructed faith world is of existential importance for these 'bridging interpreters' linking the ancient Bible texts with modern issues.

As a caveat, however, with some studies on 'non-academic' or 'lay' or 'primary' or 'from below' readings of the Bible, one at times cannot escape a sense that these readings are in certain ways romanticised, or idealised, perhaps even awarded greater legitimacy than more academically informed readings, because of scholars' natural sympathies with such readers. Here, in this contribution, that is not the case. These are not presented as models to be emulated. Certainly, these three cases discussed below render neither views I subscribe to nor exegetical pathways I could recommend. Still, as indicated above, there is sense in giving attention to these interpretations: by looking into concave and convex mirrors, we do manage to see ourselves differently. We then go on to look into our usual mirrors more attentively.

\section{The Bible, diachronically/ diagnostically studied}

The theories which have as intention the explanation of the different ways in which particularly the Old Testament texts have come into being are well known in academic circles. 
Moving on from the earlier, intellectually unsatisfying attempts to understand historical processes (cf. the history of Pentateuchal exegesis in Houtman 1994), the pendulum of explaining the growth of these texts within mainstream Old Testament scholarship on particularly Pentateuch Studies has swung widely (cf. Finkelstein \& Römer 2014:317-318 for a recent brief summary). All of these theories try to discern patterns in the coming-into-being of these texts from both oral and written sources, until they are at a certain time edited together, during which time and in later phases the texts underwent further interpretative and framing processes, commonly known by the technical term Fortschreibung. At times, and not fully unrelated to these identified historical approaches, psychological interpretations of Pentateuchal text have been offered (cf. Scheffler 1994:148-159 and more recently van der Zwan 2016 for overviews). The latter approaches usually have to do with symbolism taken up in the texts and how these may affect engagements with these texts. However, in rare instances proposals are made that go one step further and offer medicalpsychological diagnoses as interpretative key with which to explain characteristics of the texts. Two instances of such 'diagnostic' attempts will serve to illustrate this approach.

Altschuler (2004:870), a US-based psychiatrist, offers in the Letters column of the The South African Medical Journal an understanding of an aspect of Pentateuch authorship on the basis of his previous, broadly parallel note on Ezekiel (Altschuler 2002:561-562). In the latter, he identified medical symptoms of temporal lobe epilepsy on the part of Ezekiel. This view, though taken note of in passing here and there among exegetes (e.g. Joyce 2007:56), received warmest reception in less academically oriented fora (e.g. Motluk 2001, Irvine 2015:47). Altschuler's views in this regard are succinctly summarised in a text book on Clinical Neurology (Feinsod 2010:41):

In a scholarly but short article, Altschuler (2002) claims that the prophet Ezekiel had temporal lobe epilepsy. His analysis of the book brings out all that he thinks are necessary ingredients for this diagnosis - extreme religiosity coupled with aggressive and pedantic prophecies, concern with the minute details of the temple, repetitive hypergraphia, and criticism of women's sexual behavior, multiple fainting spells, and sticky personality. His diagnosis is open to debate. Several assumptions seem to be quite subjective, but the subject certainly deserves further study. (Ross 1978)

Drawing on his 2002 published view, Altschuler applies this to the Priestly source of the Pentateuch (a Priestly source which he understands in the classical way put forward by Wellhausen 1883, but since the 1970s foundationally contested by other historical models), proposing a diagnosis of epilepsy for the Priestly Writer (P):

In 1975 Waxman and Geschwind noted a constellation of signs and symptoms in some patients with TLE [Temporal Lobe Epilepsy], viz. hyperreligiosity, hypergraphia, and altered sexual behaviour during interictal periods. Other signs of this 'Geschwind syndrome' ${ }^{3}$ can include aggression and pedantic speech. Many patients with TLE do not demonstrate this

\footnotetext{
3.This syndrome consists simply of the symptoms associated with such epilepsy.
}

flagrant 'temporal lobe personality'; however, when present it is quite characteristic, especially the sign of hypergraphia.

As can easily be discerned from the [Bible] text, $\mathrm{P}$ writes in a pedantic and aggressive style, e.g. (Leviticus 26:27-29) 'And if, through this, you will not listen to me, ... you will eat your sons' flesh, and your daughters' flesh you will eat'. While clearly pious and devout, $\mathrm{P}$ also shows extreme religiosity, concern with the process and mechanistic workings of a given religion or religions, e.g. lengthy sections in minute and exacting detail on the very dimensions of construction blueprints, priestly garments and sacrifice (Exodus chapters 26-30, Leviticus chapter 7) - not seen in the remarkable stories of $\mathrm{J}$ and $\mathrm{E}$. The $\mathrm{P}$ text is more than twice as long as the J, E, D or R texts and demonstrates a redundant style typically seen in TLE. P is a dogged regulator of sexual behaviour, with repeated proscriptions (e.g. Leviticus chapters 18-20). No evidence is present in the text that the author of the P text suffered from seizures; however, P offers no personal information, unlike in Ezekiel where some is found (2004:870).

While the authors of both the P text and the Book of Ezekiel demonstrate most of the key features of the interictal TLE personality, the lens of TLE is useful in comparing their texts, showing differences in style, consistent with current thinking that they were written by different authors. Thus, $\mathrm{P}$ is also then the oldest known case of TLE. (Altschuler 2004:870)

References to Altschuler are found in a number of Health Science texts, with e.g. Devinsky and Lai (2008:637) employing his work, but with Valiente-Barroso and GarcíaGarcía (2010:233) unexpectedly independently drawing up their own list of important figures from religious history who may be said to have had epilepsy. Usually when Altschuler is referred to in such medical texts, it is done as part of a brief historical overview section, at times with a call for further exploration, and at times with a hint of apprehension. The latter could most easily be based on methodology: can such an ancient text as one from the Hebrew Bible be used as a reliable instrument of diagnosis? More importantly for the present undertaking, though, is the question: why would such an analysis be attempted and then find rather widespread readership?

More self-critical (Murray, Miles \& Bruce 2012:419-423), nevertheless confident enough to propose from their analysis a new diagnostic subcategory for the American Psychiatric Association's highly influential Diagnostic and Statistical Manual of Mental Disorders (Murray et al. 2012:423424), is a publication on four Bible figures - Abraham, Moses, Jesus and Paul (Murray et al. 2012:410-426). To keep for the moment only to the Pentateuchal scope above:

- Apparently aware of some critical aspects of historical scholarship on Abraham, but nevertheless accepting a 175-year life span for this patriarch of ancient Israel, Abraham according to this description has auditory and visual hallucinations, religious delusions and paranoidschizophrenic thoughts. An unexpected logic of negative diagnosis is followed, excluding various possible medical explanations for unusual episodes from the Pentateuch related to Abraham (tabled in Murray et al. 2012:413), 
concluding to an only other explanation as follows (Murray et al. 2012):

The absence of apparent affective, medical, or neurological conditions increases the possibility that a psychotic disorder could have been present. Schizophrenia is often accompanied by both disorganized behavior and thought processes that interfere with life functioning. In the case of Abraham and in the others that follow, disorganization and cognitive impairments are not apparent. Paranoid schizophrenia (PS), however, is a subtype of schizophrenia that tends to manifest little or no disorganization, has preserved functional affect, and is associated with better occupational and social functioning ... Abraham stands as the earliest case of a possible psychotic disorder in literature. (pp. 412-413)

- As to Moses, a similar kind of deduction is made: 'Many of these features may occur together in schizophrenia, affective disorders, and schizoaffective disorder' (Murray et al. 2012:413). Although the occurrence of symptoms with Moses is formulated carefully, almost tentatively, the matter is sealed when (Murray et al. 2012): ${ }^{4}$

[i]t should be noted that the religious writings attributed to Moses' authorship, the Pentateuch, could suggest the presence of an exaggerated urge to write. Such hypergraphia is a nonspecific finding more commonly associated with mania, hypomania, or mixed states; however, it is also a feature of schizophrenia and temporal lobe epilepsy. (p. 414)

Although the central question is, 'On what basis do we distinguish between the experiences of psychiatric patients and those of religious figures in history?' (Murray et al. 2012:410-411), the conclusion rather follows that:

based on the available descriptions that mention features bearing a striking resemblance to psychotic symptoms and the absence of mention of events resembling overt seizures, it is more parsimonious to explain these experiences as potentially due to a primary psychiatric condition. (Murray et al. 2012:417)

Criticism of both these featured publications (Cook 2012:225229 reviews further instances of this approach) from the viewpoint of mainstream critical theological scholarship would include a number of aspects. These would include that only a vague sense of appreciation is shown for the vastly different thought worlds between the ancient and modern worlds, famously formulated already by Lessing (1777 [1979]:13) as 'der garstig breite Graben'. Related to this, one encounters no awareness of the issues related to hermeneutics (cf. foundationally Thiselton 1992). As to exegetical concerns, no critical engagement with the texts concerned is found, in the sense of taking their compositional and editorial histories seriously. The latter is perhaps the most striking methodological flaw, which may have substantially hampered the very idea of proposing diagnoses from Bible texts. Perhaps the broad strokes with which these diagnoses are undertaken and the intensely detailed textual analyses that characterise Bible scholarship stand at odds in this respect. Two different scholarly protocols occur here. This then becomes an example of cross-disciplinary academic work in which the threshold of 4 Somewhat surprisingly here without reference to Altschuler's earlier work. understanding the nuances of the incorporated discipline, in this case Biblical Studies, ${ }^{5}$ has not been reached. Yet more broadly, the sociological question on the medicalisation of ever-increasing sections of the human endeavour (cf. Illich 1975:73-77) could be raised here too.

Important for the present investigation is to highlight the possible reasons why this medical-diagnostic endeavour to solving interpretative riddles would be undertaken.

On a broad cultural front may well lie here, in the background, the recurring perceived problematics of science-and-religion, or science-versus-religion, highlighted again widely in 2009 with the celebration of the 150th anniversary of the publication of Darwin's The origin of species (1859). In this respect, publications such as these may be understood as taking a step from within the natural sciences paradigm to approach the theological, namely by keeping to the protocols of the former, and thus by implication asserting anew the legitimacy of the latter. Contestable as such a methodology is, it may belie more personal reasons, namely faith commitments on the part of the authors, who hence find themselves drawn to such a form of apologetics (in the classical sense, here, of formulating faith in a presently understandable way). This would thus make of these two medical-diagnostic contributions something akin to missiological attempts; not tracts, exactly, but certainly - to invert for the moment Anselm's famous dictum - understanding seeking faith.

This kind of spirituality may be characterised as modernist, in the sense that what is understood as a natural-scientific manner of understanding is taken as the point of departure. From there, what is held dear, in this case convictions which include that the Bible texts remain of interest, is approached. What is believed about these texts is hoisted onto the platform of certain aspects of reason. This of itself is an act of expression of faith that at the very least includes that these texts are worthy of intellectual scrutiny. Two aspects that are of implicit importance for the authors concerned are brought together: their views on the Bible and on science. Awkward as this may perhaps seem for observers who maintain other points of departure, the integrity of this interpretative process on the part of these authors remains clear to see. Within the worldview of these authors, an attempt is made to unite natural science, here in its guise as medical science, with a spiritual observance that holds the texts of the Bible to be at least important enough that its apparent anomalies are noticed and explanations are proposed. Although more thoroughgoing faith commitments on the part of these authors concerned may be surmised, such biographical dimensions are not apparent in these writings of theirs. Enough is presented by them, though, that serious medically formed analyses of the Bible texts show at least an intellectual kind of engagement these scriptures which neither forego them nor their idiosyncrasies.

5.The other disciplines drawn on are in this contribution not analysed, except that the superficiality of such work should be noticed too. 


\section{Eden, Nigeria and Igbo pre-Adam}

Of an altogether different kind of engagement with the Old Testament texts is that of particularly Catherine Acholonu, a Nigerian public intellectual deceased in 2014. Although her work had some wider reverberations, these were always with a Nigerian focal point. Acholonu's more specific reference point was the Igbo tribe, on which she wrote in a kind of anthropologically historical or culturally historical mode. Four of her books are of particular interest in this respect:

- 2005: The Gram Code of African Adam: Stone Books and Cave Libraries, Reconstructing 450000 Years of Africa's Lost Civilizations

- 2009: They Lived Before Adam: Pre-Historic Origins of the Igbo - The Never-Been-Ruled (Ndi Igbo since 1.6 million B.C.)

- 2010: The Lost Testament of the Ancestors of Adam: Unearthing Heliopolis/Igbo Ukwu - The Celestial City of the Gods of Egypt and India

- 2014: Eden in Sumer on the Niger: archaeological, linguistic, and genetic evidence of 450000 years of Atlantis, Eden, and Sumer in West Africa

Her central precept in these works is that the Igbo cultural group predated the biblical Adam and Eve (literally understood), and had a highly developed culture which influenced the world, and still does, via these two progenitors. By noticing parallels across religions and cultures of the globe, the conclusion is drawn that these are remaining reverberations of this ancient Igbo high culture. High culture, because with the onset of the creation of Adam and Eve, the species takes a decidedly backward evolutionary step. A prebiblical Eden therefore existed in what is now Nigeria. Yet, in many still employed symbols and practices this enduring influence from ancient Nigeria is said to be detectable, across the world, with Davis (2012) uniting many of these aspects under what he terms 'Igbonomics'. After spending research time at the Catherine Acholonu Research Foundation in Abuja, he with this work namely seeks to present the spirituality, cosmology and science of African metaphysics as the unified field theory of everything'.

The methodology of both of these authors may be described as highly interpretative, unintentionally exchanging the protocols of the natural sciences and the philosophies of science $^{6}$ for what may perhaps be called cultural observance (with the double meaning of the latter term here intentional). Although presented as culturally comparative and as textually analytical work, with, for example, recurring terminology such as that a close reading of particular Bible texts and archaeological findings would reveal conclusions supporting their views, these works are more conjectural in nature. No textual analyses are shown, nor any in-depth cultural or historical comparisons presented.

An underlying, strongly loyal sentiment towards Igbo culture is noticeable. Oral tradition and DNA evidence are said in international scholarly enterprise, since her Master's and Doctoral studies had been undertaken in Germany. combination to overturn received biblical history and evolutionary insight, setting ancient Igbo culture as a primary, and elevated, reference point. Acholonu stresses for instance that 'Igbo land' is the home of earliest humanity, using language from the natural sciences such as the human genome project' to support the veracity of her statements. Though such a kind of argumentation is of itself not unwelcome in historical reconstructions relating theology to identity (in le Roux 2003, for instance, this is done in a more scholarly way relating to the Lemba tribe), the manner of declaring validity rather than arguing it (cf. Loader 1978:10) detracts from the credibility of the work.

A note of triumphalism can be detected in such 'findings' by Acholonu, and implications for a kind of Igbo and Nigerian nationalism are indicated. In relating Nigerian tribal loyalties to theological motifs, she is not entirely alone. Compare for instance Bascom's volumes Ifa divination: communication between gods and men in West Africa (1969) and Sixteen cowries. Yoruba divination from Africa to the new world (1980), in more traditional scholarly format, and in a manner somewhat closer to the committed mode of Acholonu, Adamo's 2015 article, perhaps tacitly reacting to Acholonu's Igbo emphasis with his accent on the Yoruba culture in Nigeria, 'Ancient Israelite and African proverbs as advice, reproach, warning, encouragement and explanation'.

Whereas in the previous section a medical-scientific framework was the context in which the Bible texts were read, here, most particularly with Acholonu and her closest associates, a culturally affirming matrix seems to form the interpretative context. Within Nigerian society, this proved influential, with Acholonu becoming, because of these and other literary publications, a cultural advisor to the presidency. Noteworthy as far as the Bible references are concerned is that these texts are taken at face value, with a literalist reading of these as well as other ancient cultural artefacts. Yet, the understanding is not related to what would be common in Western-style fundamentalist Bible readings, in which the 'In the beginning ...' reference in Genesis 1:1 is taken to refer to an absolute beginning. Acholonu proposes a race predating the Genesis creation accounts. In a way, read together with her implied loyalties to Igbo identity, this establishes part of the Nigerian self-awareness as earlier, which means more foundational, than the biblical creation accounts.

In what may well be a deeply existential search for cultural legitimacy, perhaps as part of the anti-colonial impulses found in various ways across the African continent (though nowhere as harshly as in South Africa), the Bible is still drawn on, but then in a way superseded by the proposed priority of Igbo culture. The Bible is thus still important in this spiritual quest, though more as a stepping stone towards greater selfworth than as a kind of final authority. Whereas it is fully acknowledged in Spirituality Studies that culture plays an important constitutive role in shaping spirituality, including Christian spiritualities as Bible-centred spiritualities, in this instance the cultural loyalty predominates, explicitly to an extent not observed elsewhere. The Bible plays an unusual, perhaps unique role within this spiritual identity. 


\section{Holy smoke}

Finally to turn to a different, in some sense more traditional way of relating the Bible to existential-religious practice, the Rastafarian use of marijuana as a 'spiritual herb' (e.g. Steffens \& Smith 1987:49; cf. Nichols \& Chemel 2006:1-33; Winkelman 2006:139-159; Roberts 2006:235-267) finds support for this practice in the legitimating interpretation of certain Bible texts. Although some anthropological theories on the origins of religion relate above-human experiences to chemically induced states of consciousness, and although such body chemistry indeed has effects on the individual (cf. McNamara 2006), these are not the kinds of arguments typically found amongst Rastafarians. The internal logic within Rastafarianism runs its own course, for instance linking the Jamaican musician Bob Marley with the Ethiopian politician Haile Selassie, often called Ras Tafari, as the reincarnate Jesus Christ (cf. Barrett 1997; Edmonds 2003). Referring to God as Jah, an abbreviation of the Tetragrammaton $\mathrm{YHWH}$, and paralleling its own history to that of the Israel of the Exodus book, this religious movement clearly understands itself as, at least in some ways, linked to the Bible, Judaism and Christianity.

That such links do not fully follow traditional Christian understandings of Bible verses becomes most apparent when biblical support is sought for the semi-sacramental use of marijuana. As Pretorius (2006:1021; italics added) relates this:

Rastas cite Bible verses to justify their use of herbs, particularly ganja. Genesis 1:29: 'And God said, Behold I have given you every herb bearing seed, which is upon the face of the earth, and every tree, in which is the fruit of a tree yielding seed; to you it shall be for meat' (Erskine 2005:96); Genesis 3:18: ' ... thou shall eat the herb of the field'; Exodus 10:12: '... eat every herb of the field'; Proverbs 15:17: 'Better is dinner of herb where love is, than a stalled ox and hatred therewith'; Psalm 104:14: 'He causeth the grass to grow for the cattle, and herb for the service of man'. Another text that underscores their view is Revelation 22:2: '... the leaves of the tree were for the healing of the nation'. Rastas even suggest, based on Psalm 18:8, that God enjoys smoking ganja: 'There went up a smoke out of his nostrils, and fire out of his mouth devoured: coals were kindled by it (Erskine 2005:96)'.

Although not meant as playful interpretations, these could easily be construed as such. The closest to academic respectability this line of thinking could claim is the 2008 article by Shannon, 'Biblical entheogens: a speculative hypothesis', in which he proposed that the divine visions Moses experienced may be related to the use of mind-altering plants. This possibility, as with the Rastafarian interpretation of some Bible verses related in the paragraph above, has found no following in mainstream academia. Whereas the Shannon proposal may be understood to be in the same mode as that of the examples from the world of medicine above, the Rastafarian readings are more earthy. Once key terms such as 'herb' and 'leaf' have been identified, an almost concordance-like skimming of Bible texts follows, though seldom in such a systematised manner as related above.

One cannot escape the sense that, had such verses been absent from the biblical literatures, Rastafarians would not have desisted from marijuana use. At play here are cultural habits as much as any other factors. The Bible verses are thus employed for the sake of ex post facto legitimation, as is the case with many cultural and other practices in religions and spiritualities that lie in the wake of the Bible texts. The kind of biblical spirituality that may be identified in such cases is that the Scriptures do not play a critical role, but are sought in support of current sensibilities. The fact that the Bible is indeed called upon is not without significance: it is still regarded as a source of authority on the expression of faith. However, the metaphor employed in Lombaard (2001:69-87) may here too be apt: that the Bible is used as a ventriloquist would use a puppet, namely to mouth what the puppet master wants.

\section{Again: Biblical and Umbilical Spirituality?}

When the relationship between context and spirituality is discussed, ${ }^{7}$ the standard position is that context is not spiritually determinative, but rather facilitative. The more difficult critical question to ask, springing from this, is: is a delimiting effect possible too, and if so, in a linear manner, or reciprocally? In which circumstances may context and spirituality offer (mutual?) restraint, for instance in guiding the ways in which the Bible is employed? How do people, religiously inclined or not, sense which interpretations of these texts may be legitimate, and which not?

Above, three kinds of holiness relationships with the texts of the Bible have been surveyed for illustrative purposes. Firstly, and at the very least, intellectual reverence relating to the Bible leads to reference of the Bible. Secondly, an unfolding cultural impulse towards hegemony subsumes the Bible to its sense of rising importance. Thirdly, the Bible is drawn on in order, with greater authority, to declare holy what is already experienced as holy. None of these kinds of 'holiness relationships', the integrity of which on the part of the interpreters seem in all cases to be above reproach, guarantee that standard, broadly accepted and exegetically acceptable, interpretations are arrived at.

Interestingly, none of the examples referred to above holds explicitly to any apparent inspiration theory; yet all accord the Bible a kind of status, namely as something worth taking cognisance of, to the extent that what is perceived as a legitimate interpretation is then concluded to. Although all three offer their respective readings to the benefit of an implicit, intended receiver group, there is not a strong sense in favour of the worth of intellectual engagement with either the broader scholarly body of literature or with other biblically interpretative literature within this intended readership group. To a large extent, hence, these are somewhat isolated contributions, yet not offered with the intent to remain fringe insights. Although in some respect, thus, these interpretations may tend towards being private revelatory moments, they are meant for broader 7.Among the most well-known works within Spirituality Studies on context counts e.g. Sheldrake (2007:4-11, 205-209). 
enlightenment: no isolationist pietism, but service to the broader community is the view. In this latter respect, these understandings are no different from most mainstream scholarly contributions within theology.

Although the historic routes of these divergent views are easily traceable, the revealing question remains: where lie, outside of the 'insider' community of interpretation, the boundaries between marginal and mainstream Bible understanding? Can it be only the size of the interpretative community that determines legitimacy? - However, all the presently large Christian groupings started off as minorities. Can it be only the longevity of an understanding that determines its legitimacy? However, exegetical history offers ample examples of minor insights becoming major understandings, either through exegesis (as in the Genesis and evolution creation understandings) or through altered hermeneutics (as had been the case relating to slavery, gender relations and currently same sex relationships). Where, then, lie the boundaries between marginal and mainstream Bible understanding?

Such questioning becomes all the more important with the current growth in mystical engagements with the Bible texts, while at the same time fervently fundamentalist textual readings and missionary anti-religious detractions from the value of the Bible texts compete quite fiercely in the public religious and political arenas.

In Christian theology it would be a natural recourse to refer to the guidance of the Holy Spirit in understanding the Holy Scriptures. Yet, this foundational stance, valid as it is as an article of faith, answers none of the probing questions a survey such as this pushes to the fore. One of the core ancient religious issues remains with us still, although in new times anew: When is spirituality in general and Christian spirituality in its various occurrences unbiblical, and when is it biblically umbilical?

\section{Acknowledgements Competing interests}

The author declares that he has no financial or personal relationships which may have inappropriately influenced him in writing this article.

\section{References}

Acholonu, C., 2005, The gram code of African Adam: Stone books and cave libraries, reconstructing 450,000 years of Africa's lost civilizations, CARC Publications, Abuja.

Acholonu, C., Prabhakar, A. \& Animalu, A., 2010, The Lost Testament of the Ancestors of Adam: Unearthing Heliopolis/Igbo Ukwu - The Celestial City of the Gods of Egypt and India, CARC Publications, Abuja.

Acholonu, C.O, 2009, They lived before Adam: Pre-historic origins of the Igbo - The never-been-ruled (Ndi Igbo since 1.6 million B.C.), CARC Publications, Abuja.

Acholonu, C.O., 2014, Eden in Sumer on the Niger: Archaeological, linguistic, and genetic evidence of 450,000 years of Atlantis, Eden, and Sumer in West Africa (African Digital Education Series Book 2), CARC Publications, Abuja.

Adamo, D.T., 2015, 'Ancient Israelite and African proverbs as advice, reproach, warning, encouragement and explanation', HTS Teologiese Studies/Theological Studies 71(3), 1-11. http://dx.doi.org/10.4102/hts.v71i3.2972

Altschuler, E.L., 2002, 'Did Ezekiel have temporal lobe epilepsy?', Archives of Genenera Psychiatry 1877(59), 561-562. http://dx.doi.org/10.1001/archpsyc.59.6.560
Altschuler, E.L., 2004, 'Temporal lobe epilepsy in the priestly source of the Pentateuch' The South African Medical Journal 94(11), 870.

Barrett, L.E., 1997, The Rastafarians, Beacon Press, Boston, MA.

Bascom, W., 1969, Ifa divination: Communication between gods and men in West Africa, Indiana University Press, Bloomington, IL.

Bascom, W., 1980, Sixteen cowries. Yoruba divination from Africa to the new world, Indiana University Press, Bloomington, IL.

Cook, C.C.H., 2012, 'Psychiatry in scripture: Sacred texts and psychopathology', The Psychiatrist 36(6), 225-229. http://dx.doi.org/10.1192/pb.bp.111.036418

Darwin, C., 1859, The origin of species by means of natural selection, or the preservation of favoured races in the struggle for life, John Murray, London.

Davis, S., 2012, 'Igbonomics - The spirituality, cosmology and science of African metaphysics as the unified field theory of everything', paper presented at the 5th International Seminar on Theoretical Physics and National Development, at the National Mathematical Centre (NMC), Abuja, Nigeria, 15-20th July.

Devinsky, O. \& Lai, G., 2008, 'Spirituality and religion in Epilepsy', Epilepsy \& Behavior 12(4), 636-643. http://dx.doi.org/10.1016/j.yebeh.2007.11.011

Edmonds, E.B., 2003, Rastafari, Oxford University Press, New York.

Feinsod, M., 2010, 'Neurology in the Bible and the Talmud', in S. Finger, F. Boller \& K.L. Tyler (eds.), History of neurology, vol. 95: Handbook of clinical neurology, pp. 37-48, Elsevier, Edinburgh.

Finkelstein, I. \& Römer, T., 2014, 'Comments on the historical background of the Jacob narrative in Genesis', Zeitschrift für die alttestamentliche Wissenschaft 126 317-338. http://dx.doi.org/10.1515/zaw-2014-0020

Erskine, N.L., 2005, From Garvey to Marley. Rastafari Theology, University Press of Florida, Gainesville, FL.

Goedgebuure, J., 1993, De Schrift herschreven. De bijbel in de moderne literatuur, Amsterdam University Press, Amsterdam.

Houtman, C., 1994, Der Pentateuch. Die Geschichte seiner Erforschung neben einer Auswertung, Kok Pharos, Kampen.

Huls, J., 2006, 'From theology to mystagogy. The interiorisation of the Protestant tradition by a world citizen: Dag Hammarskjöld', in P. De Villiers, C. Kourie \& tradition by a world citizen: Dag Hammarskjold, in P. De Villiers, C. Kourie \&
C. Lombaard (eds.), The Spirit that moves. Orientation and issues in spirituality C. Lombaard (eds.), The Spirit that moves. Orientation and issues in spirituality
(Acta Theologica Supplementum 8), pp. 84-98, University of the Free State Press, (Acta Theologica
Bloemfontein.

Illich, I., 1975, 'The medicalization of life', Journal of Medical Ethics 1(2), 73-77. http:// dx.doi.org/10.1136/jme.1.2.73

Irvine, W.B., 2015, Aha! The moments of insight that shape our world, Oxford University Press, Oxford.

Joyce, P.M., 2007, Ezekiel. A commentary (The Library of Hebrew Bible/Old Testament Studies 482), T\&T Clark, New York.

Kombuis, K., 2003, The secret diary of God (aged 91/2 million trillion years), Zebra Press, Cape Town.

Le Roux, M., 2003, The Lemba: A lost tribe of Israel in Southern Africa? Unisa Press, Pretoria.

Lessing, G.E., 1777, 'Über den Beweis des Geistes und der Kraft', in H.G. Göpfert (Hrsg.), 1979, Werke, 8. Bd.: Theologiekritische Schriften III, Philosophische

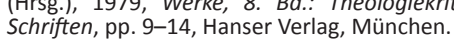

Loader, J.A., 1978, 'The use of the Bible in conventional South African theology', in W. Vorster (ed.), Scripture and the use of Scripture, pp. 1-25, Unisa, Pretoria.

Lombaard, C., 2001, 'The Bible in the apartheid debate', in J.W. Hofmeyr, C.J.S Lombaard \& P.J. Maritz (eds.), $1948+50$ years. Theology, apartheid and church: Past, present and future (Perspectives on the Church/Perspektiewe op die Kerk Series 5: Vol. 1), pp. 69-87, IMER (Institute for Missiological and Ecumenical Research), University of Pretoria, Pretoria.

Lombaard, C., 2010, Buchan brou, viewed 29 September 2016, from http://www.litnet co.za/Article/buchan-brou / http://teo.co.za/buchan-brou / http://blogs.litnet. co.za/gerritbrand/2010/05/31/lombaard-skryf-buchan-brou / http://uir.unisa.ac. $\mathrm{za} /$ bitstream/handle/10500/13819/Geredigeer $\% 20$ ChristoLombaardBuchan $\% 20$ brou.pdf?sequence $=129$ September 2016 .

Lombaard, C., 2011, 'Biblical spirituality and interdisciplinarity: The discipline at crossmethodological intersection', Religion \& Theology 18, 211-225. http://dx.doi. org/10.1163/157430111X613737

Lombaard, C., 2012, 'Betwixt text and nature, God and evolution: Biblical reception and creationism at the creation museum in cultural-anthropological perspective', in C. Lombaard (ed.), The Old Testament and Christian Spirituality. Theoretical and practical essays from a South African perspective (International Voices in Biblical Studies 2) pp. 139-169, Society of Biblical Literature, Atlanta, GA, viewed 29 September 2016, from http://ivbs.sbl-site.org/uploads/SBL\%20book\%20(final\%20edit).pdf

Lombaard, C., 2014, 'Mysticism and understanding: Murmurs of meaning(fulness) Unheard Silences of Psalm 1', Old Testament Essays 27(2) (special edition for Harry van Rooy), 472-488.

Lombaard, C., 2015a, 'Mysticism and/in the Old Testament: Methodological orientation and a textual example', HTS Teologiese Studies/Theological Studies 71(1) (special edition for PGR de Villiers), 1-5. http://dx.doi.org/10.4102/hts.v71i1.2813

Lombaard, C., 2015b, 'Hol(e)y texts; Hol(e)y lives: On the Psalms and Spirituality. With particular attention to Thessalonia DePrince, Thomas Merton and Beat Weber Described, compared and evaluated', Scriptura 114(1), 1-13. http://dx.doi. org/10.7833/114-0-1139

Lombaard, C., 2016, “'Take it easy ...” (The Eagles): A rockin' 'n rollin' use of the Psalms in Christian spirituality', Guest lecture at the Lutheran School of Theology in Aarhus, Denmark, 3rd May 2016. 
Mahoney, E.J., 2000, Scripture as the soul of theology, Liturgical Press, Collegeville, PA. McNamara, P. (ed.), 2006, Where God and science meet. The psychology of religious experience, vol. 3, Praeger Publishers, Westport, CT.

Milligan, S., 1994, The Bible - The Old Testament according to Spike Milligan, Penguin Books, London.

Motluk, A., 2001, 'Old Testament prophet showed epileptic symptoms', New Scientist 17 November 2001, viewed 7 May 2016, from www.newscientist.com/article/ dn1565-old-testament-prophet-showed-epileptic-symptoms

Murray, E.D., Miles, G.C. \& Bruce, H.P., 2012, 'The role of psychotic disorders in religious history considered', The Journal of Neuropsychiatry and Clinical Neurosciences 24, 410-426. http://dx.doi.org/10.1176/appi.neuropsych. 11090214

Nichols, D.E. \& Chemel, B.R., 2006, 'The neuropharmacology of religious experience: Hallucinogens and the experience of the divine', in P. McNamara (ed.), Where God and science meet. The psychology of religious experience, vol. 3, pp. 1-33, Praeger Publishers, Westport, CT.

Pretorius, S.P., 2006, 'The significance of the use of ganja as a religious ritual in the Rastafari movement', Verbum et Ecclesia 27(3), 1012-1030. http://dx.doi. org/10.4102/ve.v27i3.199

Roberts, T.B., 2006, 'Chemical input, religious output - Entheogens: A Pharmatheologogy sampler', in P. McNamara (ed.), Where God and science meet The psychology of religious experience, vol. 3, pp. 235-267, Praeger Publishers, Westport, CT.

Ross, J., 1978, 'Epilepsy in the Bible', Developmental Medicine and Child Neurology 20 677-678. http://dx.doi.org/10.1111/j.1469-8749.1978.tb15291.x
Shannon, B., 2008, 'Biblical entheogens: A speculative hypothesis', Time and Mind 1(1), 51-74. http://dx.doi.org/10.1111/10.2752/175169608783489116

Scheffler, E., 1994, 'The psychological approach to the (Hebrew) Bible', Old Testament Essays 7, 148-159.

Sheldrake, P., 2007, A brief history of spirituality, Blackwell Publishing, Oxford.

Steffens, R. \& Smith, C.C. (eds.) 1987, The Reggae \& African Beat. 5th annual Bob Marley collectors edition, vol. VI, Bongo Productions, Los Angeles, CA.

Thiselton, A.C., 1992, New horizons in hermeneutics, Zondervan, Grand Rapids, MI.

Valiente-Barroso, C. \& García-García, E., 2010, 'Aspectos neurológicos relativos a estados alterados de conciencia asociados a la espiritualidad', Revista de Neurología 51, 226-236.

Van der Zwan, P., 2016, 'Psychological approaches to the song of songs', Journal for Semitics. Forthcoming.

Waaijman, K., 2000, Spiritualiteit: Vormen, grondslagen, patronen, Carmelitana, Gent. Waxman, S.G. \& Geschwind, N., 1975, 'The interictal behavior syndrome of temporal lobe epilepsy', Archives of Geneneral Psychiatry 32(12), 1580-1586.

Wellhausen, J., 1883, Prolegomena zur Geschichte Israels, G Reimer, Berlin.

Welzen, H., 2011, 'Contours of Biblical Spirituality as a discipline', in P.G.R. De Villiers \& L.K. Pietersen (eds.), The Spirit that inspires. Perspectives on Biblical Spirituality (Acta Theologica Supplementum 15), pp. 37-60, University of the Free State Press, Bloemfontein.

Winkelman, M. 2006, 'Cross-cultural assessments of shamanism as a biogenetic foundation for religion', in P. McNamara (ed.), Where God and science meet. The psychology of religious experience, vol. 3, pp. 139-159, Praeger Publishers, Westport, CT. 